\title{
Edible Seeds and Nuts Grown in Brazil as Sources of Protein for Human Nutrition
}

\author{
Jullyana B. Freitas ${ }^{1,2}$, Daniela C. Fernandes ${ }^{1}$, Ludmila P. Czeder ${ }^{1}$, Jean Carlos R. Lima ${ }^{1}$, \\ Amanda G. O. Sousa ${ }^{3}$, Maria Margareth V. Naves ${ }^{4 *}$
}

${ }^{1}$ Faculty of Agronomy and Food Engineering, Federal University of Goiás (UFG), Goiânia, Brazil; ${ }^{2}$ Department of Academic Areas I, Federal Institute of Education, Science and Technology (IFG), Goiânia, Brazil; ${ }^{3}$ Department of Nursing, Nutrition and Physiotherapy, University Pontifical Catholic of Goiás (PUC-GO), Goiânia, Brazil; ${ }^{4}$ Experimental Nutrition Laboratory, Faculty of Nutrition, Federal University of Goiás (UFG), Goiânia, Brazil.

Email: *mnaves@fanut.ufg.br

Received April $3^{\text {rd }}, 2012$; revised May $3^{\text {rd }}, 2012$; accepted May $12^{\text {th }}, 2012$

\begin{abstract}
Edible seeds and nuts can contribute to an adequate intake of protein, particularly in vegetable-based diets. However, there are relatively few reports with insufficient data regarding the protein quality of these foods, especially of edible seeds and nuts from Brazil. The aim of this study was to investigate the chemical composition and in vivo protein quality of two edible seeds (baru almond and peanut) and two nuts (Brazil nut and cashew nut) grown in Brazil. The proximate composition and the amino acid profile were analyzed. The true protein digestibility and the protein quality of these foods were evaluated by bioassay with male weanling Wistar rats over a period of 14 days, and the Protein Digestibility Corrected Amino Acid Score (PDCAAS) was estimated. Edible seeds and nuts presented high contents of proteins (16.3 to $32.3 \mathrm{~g} / 100 \mathrm{~g}$ ), lipids (42.7 to $57.9 \mathrm{~g} / 100 \mathrm{~g}$ ) and dietary fibers (6.5 to $14.3 \mathrm{~g} / 100 \mathrm{~g}$ ). Lysine was found to be the limiting amino acid in baru almond, peanut and Brazil nut, which had amino acid scores ranging from $71 \%$ to 76\%. Cashew nut had no limiting amino acid. These foods showed high protein digestibility (around 90\%) except for baru almond (75\%), and their PDCAAS values varied significantly (57\%, for baru almond, and $90 \%$, for cashew nut). The edible seeds and nuts grown in Brazil provide a high density of energy and nutrients and they can be used as complementary sources of proteins.
\end{abstract}

Keywords: Edible Seeds; Nuts; Amino Acids; Chemical Composition; Protein Bioavailability

\section{Introduction}

Traditional nuts are thick dried fruits known across the world as almonds, Brazil nuts, cashew nuts and walnuts $[1,2]$. Brazil is one of the largest producers of Brazil nut (Bertholletia excelsa H.B.K.) and cashew nut (Anacardium occidentale L.), which grow in the Northern and North-eastern regions of the country [3]. The Midwest region of Brazil produces the baru almond (Dipteryx alata Vog.), an edible seed from the fruit of the baru tree, which belongs to the legume species (Fabaceae family) and is native of the Brazilian Savanna [4]. The peanut (Arachis hypogaea L.), another edible seed of the legume species [1], is very commonly consumed worldwide, including in Brazil.

Edible seeds and nuts have high contents of lipids, proteins, dietary fiber and ashes (minerals) and they have a good essential amino acids profile, usually with a slight lysine deficiency [2,5]. However, relatively few studies

\footnotetext{
*Corresponding author.
}

have investigated the protein quality of these foods, especially the edible seeds and nuts from Brazil. These oleaginous could be important sources of protein and bioactive compounds for vegetable-based diets as well as in an ordinary healthy diet since their intake is associated with a reduced risk of chronic diseases [6,7].

Considering their nutritional potential, this study aimed to investigate the chemical composition and in vivo protein quality of the following edible seeds and nuts grown in Brazil: a native edible seed from the Brazilian Savanna-baru almond; an edible seed with worldwide consumption-peanut; and two traditional nuts from BrazilBrazil nut and cashew nut.

\section{Materials and Methods}

\subsection{Plant Materials and Sample Preparation}

The native baru fruits were collected from the West region of the State of Goiás (Midwest Brazil). The peanut (HPS variety), Brazil nut and cashew nut were purchased 
in Goiânia, province of State of Goiás. The baru almonds and the peanuts were roasted in an electric oven at $140^{\circ} \mathrm{C}$ for $30 \mathrm{~min}$ [8]. The Brazil nuts were obtained raw, without the rind, while the cashew nuts were purchased in already-roasted form, the way they are usually consumed. All the edible seeds and nuts were repeatedly milled with a blender and sieved through a 60 mesh sieve. The milled seeds/nuts were used for the chemical analysis and the experimental diets.

\subsection{Chemical Analyses}

The proximate composition of the edible seeds and nuts was determined in triplicate and included moisture, ash and protein content evaluated through nitrogen analysis using a conversion factor of 6.25 [9,10]; total lipids [11]; total dietary fiber and its fractions, soluble and insoluble [12]; and carbohydrate content, which was estimated by difference. The nitrogen and lipid contents of the diets of the bioassay were analyzed too. The energy value of the foods and diets was estimated using the Atwater conversion factors [13]. The quantification of amino acids, except tryptophan, was performed in duplicate by acid hydrolysis of proteins and peptides [14]. Tryptophan was quantified using alkaline hydrolysis [15]. Samples were then placed in an automatic amino acid analyzer (Nicolas V; Protein Chemistry Center of the University of São Paulo, Ribeirão Preto, Brazil), and quantified colorimetrically. The Amino Acid Score (AAS) was estimated in accordance with the WHO [16]: AAS $=$ [(mg of amino acid in $1 \mathrm{~g}$ of test protein/mg of amino acid in requirement pattern) $\times 100$ ].

\subsection{Animals and Experimental Design}

The experiment was performed using 42 male weanling Wistar rats (25 - 28 days old), which were randomly divided into 7 groups of 6 animals each. The animals were maintained in individual cages at a temperature of $22^{\circ} \mathrm{C} \pm$ $2^{\circ} \mathrm{C}$, relative humidity of $60 \% \pm 10 \%$, and a $12 \mathrm{~h}$ lightdark cycle for 17 days ( 3 days of acclimation and 14 days of experiment). All procedures were conducted according to the guidelines for the care and use of laboratory animals [17], and were approved by the Research Ethics Committee of the Federal University of Goiás (Protocol no. $153 / 2008)$.

\subsection{Diets and Intake Control}

The rats were treated with different diets formulated in accordance with the AIN-93G [18], and modified to contain $10 \%$ protein (Table 1).

The pair feeding method [19] was adopted to ensure the same energy intake among the animal groups: the baru almond diet was provided ad libitum, and the amount of food consumed was monitored daily. The reference, control, peanut, Brazil nut and cashew nut groups received the same intake as the baru almond group, corrected by the energy conversion factor for each diet (Table 1) in relation to the baru almond diet (food offered = baru almond food consumed $\times$ energy conversion factor).

The rats had unrestricted access to filtered water. The body weight of the rats was assessed every other day during the entire experimental period.

\subsection{Biological Indexes}

The protein quality of the edible seeds and nuts was estimated by the Protein Digestibility-Corrected Amino Acid Score (PDCAAS). In vivo true protein digestibility (\%) was determined and the PDCAAS was also calculated as described by the FAO [20], as follows: PDCAAS $(\%)=[$ AAS of the test protein $(\%) \times$ true digestibility of the test protein (\%)]/100.

\subsection{Statistical Analysis}

The results of the chemical analyses and the bioassay were compared using one-way analysis of variance (ANOVA) and the Tukey test at a 5\% probability level. STATISTICA software, Version 7.0 (StatSoft, Inc., Tulsa, OK, USA) was used for the statistical analyses.

\section{Results and Discussion}

\subsection{Proximate Composition and Amino Acid Score}

The edible seeds and nuts studied were found to contain high amounts of proteins (especially peanut), lipids (mainly Brazil nut) and dietary fiber (particularly baru almond), and they are excellent sources of energy (Table $2)$, in line with the values reported in the literature [2,5].

Baru almonds analyzed in this study (from the Western region of Midwest Brazil) had an amino acid score (AAS $=75 \%$, Table 3 ) higher than that reported for the baru almonds from the East region (AAS $=35 \%$ ) [21], and lower than the value obtained for almonds from the Southeastern region of Midwest Brazil (AAS = 92\%) [8]. This discrepancy among the AAS values denotes great variability in the essential amino acids profile and the protein quality of the baru almonds from different regions of the Brazilian Savanna.

The AAS values of the seeds and nuts studied (Table 3) were higher than that those reported in the literature for the peanut (AAS $=76 \%$ vs $68 \%$ ) and for the cashew nut (AAS $=103 \%$ vs $95 \%$ ), while the AAS value of the Brazil nut was lower than that reported in the literature (AAS $=71 \%$ vs $78 \%$ ) [2]. Lysine was the limiting amino 
Table 1. Ingredients and chemical composition of experimental diets.

\begin{tabular}{|c|c|c|c|c|c|c|c|}
\hline \multirow{2}{*}{ Component } & \multicolumn{7}{|c|}{ Diet $^{*}$} \\
\hline & Reference & Control & Baru almond & Peanut & Brazil nut & Cashew nut & Protein-free \\
\hline \multicolumn{8}{|l|}{ Ingredient (g/100g of diet) } \\
\hline Casein (76.9 g protein/kg) & 12.76 & 12.76 & - & - & - & - & - \\
\hline Baru almond & - & - & 35.77 & - & - & - & - \\
\hline Peanut & - & - & - & 30.96 & - & - & - \\
\hline Brazil nut & - & - & - & - & 61.35 & - & - \\
\hline Cashew nut & - & - & - & - & - & 43.40 & - \\
\hline L-cystine & 0.20 & 0.20 & - & - & - & - & - \\
\hline Soybean oil & 6.50 & 14.50 & - & - & - & - & 7.00 \\
\hline Cellulose & 5.00 & 5.00 & 0.20 & 2.52 & 0.15 & 3.39 & 5.00 \\
\hline Mineral mix & 3.50 & 3.50 & 3.50 & 3.50 & 3.50 & 3.50 & 3.50 \\
\hline Vitamin mix & 1.00 & 1.00 & 1.00 & 1.00 & 1.00 & 1.00 & 1.00 \\
\hline Choline bitartrate & 0.25 & 0.25 & 0.25 & 0.25 & 0.25 & 0.25 & 0.25 \\
\hline Corn starch & 70.80 & 62.80 & 59.28 & 61.77 & 33.75 & 48.46 & 83.25 \\
\hline \multicolumn{8}{|l|}{ Chemical composition } \\
\hline Proteins (g/100g) & 10.34 & 10.32 & 10.08 & 10.46 & 10.10 & 10.16 & 0.70 \\
\hline Lipids (g/100g) & 6.64 & 14.86 & 14.48 & 13.84 & 36.86 & 19.72 & 6.21 \\
\hline Energy value (kcal/100g) & 413.2 & 454.3 & 452.4 & 449.2 & 564.3 & 478.6 & - \\
\hline Energy conversion factor & 1.09 & 1.00 & 1.00 & 1.01 & 0.80 & 0.95 & - \\
\hline
\end{tabular}

*Feed formulation according to AIN-93G diet [18], with reduction of protein level to $10 \%$. Reference: casein with $7 \%$ lipids; Control: casein with $15 \%$ lipids.

Table 2. Proximate composition and energy value of baru almond, peanut, Brazil nut and cashew nut grown in Brazil*

\begin{tabular}{|c|c|c|c|c|}
\hline \multirow{2}{*}{ Component (g/100g) } & \multicolumn{2}{|c|}{ Edible seed } & \multicolumn{2}{|c|}{ Nut } \\
\hline & Baru almond & Peanut & Brazil nut & Cashew nut \\
\hline Moisture & $1.98 \pm 0.23^{c}$ & $2.18 \pm 0.02^{\mathrm{c}}$ & $6.36 \pm 0.02^{\mathrm{a}}$ & $5.34 \pm 0.09^{b}$ \\
\hline Protein $(\mathrm{N} \times 6.25)$ & $27.96 \pm 0.53^{b}$ & $32.30 \pm 1.63^{\mathrm{a}}$ & $16.30 \pm 0.56^{\mathrm{d}}$ & $23.04 \pm 0.39^{c}$ \\
\hline Lipid & $42.69 \pm 1.69^{b}$ & $44.04 \pm 0.52^{\mathrm{b}}$ & $57.94 \pm 0.71^{\mathrm{a}}$ & $44.10 \pm 0.33^{\mathrm{b}}$ \\
\hline Carbohydrate & 10.03 & 8.02 & 3.36 & 18.64 \\
\hline Total dietary fiber & $14.26 \pm 0.13^{\mathrm{a}}$ & $10.97 \pm 0.15^{\mathrm{c}}$ & $12.53 \pm 0.12^{\mathrm{b}}$ & $6.48 \pm 0.16^{\mathrm{d}}$ \\
\hline Insoluble fiber & $13.35 \pm 0.17^{\mathrm{a}}$ & $9.89 \pm 0.19^{c}$ & $11.66 \pm 0.14^{\mathrm{b}}$ & $6.18 \pm 0.20^{\mathrm{d}}$ \\
\hline Soluble fiber & $0.90 \pm 0.05^{\mathrm{b}}$ & $1.08 \pm 0.05^{\mathrm{a}}$ & $0.87 \pm 0.03^{\mathrm{b}}$ & $0.31 \pm 0.05^{c}$ \\
\hline Ash & $3.08 \pm 0.25^{\mathrm{b}}$ & $2.49 \pm 0.00^{c}$ & $3.51 \pm 0.03^{\mathrm{a}}$ & $2.40 \pm 0.02^{\mathrm{c}}$ \\
\hline Energy value (kcal/100g) & 536.1 & 557.6 & 600.1 & 563.6 \\
\hline
\end{tabular}

*Data are mean \pm standard deviation of three replicates, except carbohydrates, which were estimated by difference, subtracting from one hundred the values obtained for moisture, protein, lipid, ash and total dietary fiber. Values for a particular row followed by different letters differ significantly (p $<0.05$ ).

acid for all the seeds and nut studied except for cashew nut, which did not show any limiting amino acid (Table 3). The lysine deficiency in baru almond, peanut and Brazil nut observed in our study may not prove to be a nutritional problem, since this amino acid is found in foods in the typical Brazilian diet such as beans [10,22].

\subsection{Protein Quality}

Food and protein intakes were similar in all groups of animals but were lower for the baru almond and Brazil nut groups. The cashew nut diet was more efficient than the other experimental diets in promoting weight gain in rats, but all these diets were less efficient than the casein diets (Table 4). The weight gains of the reference (casein with 7\% lipids) and control (casein with 15\% lipids) groups were similar. The pair-feeding method was thus efficient in controlling food and energy intakes. We found peanut and Brazil nut to have the highest true protein 
Table 3. Essential amino acid composition of the baru almond, peanut, Brazil nut and cashew nut, and Amino Acid Score (AAS) according to the WHO/FAO/UNU requirement pattern*'.

\begin{tabular}{|c|c|c|c|c|c|}
\hline \multirow{2}{*}{$\begin{array}{c}\text { Amino acid (mg of } \\
\text { amino acid/g protein) }\end{array}$} & \multirow{2}{*}{$\begin{array}{l}\text { WHO/FAO/UNU } \\
\text { requirement pattern }\end{array}$} & \multicolumn{2}{|c|}{ Edible seed } & \multicolumn{2}{|c|}{ Nut } \\
\hline & & Baru almond & Peanut & Brazil nut & Cashew nut \\
\hline His & 16.0 & 25.7 & 27.7 & 27.0 & 28.4 \\
\hline Ile & 31.0 & 29.8 & 25.4 & 28.1 & 31.2 \\
\hline Leu & 61.0 & 83.0 & 64.4 & 68.9 & 69.5 \\
\hline Lys & 48.0 & 36.2 & 36.7 & 34.3 & 49.6 \\
\hline Met + Cys & 24.0 & 21.2 & 20.9 & 59.8 & 30.0 \\
\hline Phe + Tyr & 41.0 & 79.9 & 92.9 & 68.1 & 72.1 \\
\hline Thr & 25.0 & 43.4 & 30.0 & 31.5 & 37.1 \\
\hline Trp & 6.6 & 13.9 & 14.0 & 13.0 & 16.9 \\
\hline Val & 40.0 & 38.3 & 32.7 & 38.6 & 40.2 \\
\hline TOTAL & 292.6 & 371.3 & 344.7 & 369.3 & 375.0 \\
\hline AAS (\%) & 100 & 75 (Lys) & 76 (Lys) & 71 (Lys) & 103 \\
\hline
\end{tabular}

*Data are mean of two replicates. WHO/FAO/UNU requirement pattern of essential amino acids for schoolchildren [16].

Table 4. Food and protein intakes, weight gain, true protein digestibility and Protein Digestibility-Corrected Amino Acid Score (PDCAAS) in Wistar rats fed with different diets during 14 days of experiment.

\begin{tabular}{|c|c|c|c|c|c|}
\hline \multirow{2}{*}{ Diet $^{*}$} & \multicolumn{2}{|c|}{ Total intake (g) } & \multirow{2}{*}{ Weight gain (g) } & \multirow{2}{*}{ Protein digestibility (\%) } & \multirow{2}{*}{ PDCAAS $(\%)$} \\
\hline & Food & Protein & & & \\
\hline Reference & $157.04 \pm 14.76^{\mathrm{a}}$ & $16.24 \pm 1.53^{\mathrm{a}}$ & $57.2 \pm 10.5^{\mathrm{a}}$ & $95.33 \pm 0.87^{\mathrm{a}}$ & - \\
\hline Control & $150.47 \pm 10.87^{\mathrm{a}}$ & $15.53 \pm 1.12^{\mathrm{a}}$ & $58.4 \pm 5.2^{\mathrm{a}}$ & $95.27 \pm 0.67^{\mathrm{a}}$ & - \\
\hline Baru almond & $111.09 \pm 16.88^{b}$ & $11.20 \pm 1.70^{\mathrm{b}}$ & $9.2 \pm 4.0^{\mathrm{d}}$ & $75.48 \pm 0.85^{\mathrm{d}}$ & $56.6^{\mathrm{d}}$ \\
\hline Peanut & $138.99 \pm 16.92^{\mathrm{a}}$ & $14.54 \pm 1.77^{\mathrm{a}}$ & $25.3 \pm 4.4^{\mathrm{c}}$ & $91.14 \pm 0.51^{b}$ & $69.3^{\mathrm{b}}$ \\
\hline Brazil nut & $96.89 \pm 9.57^{\mathrm{b}}$ & $9.79 \pm 0.97^{\mathrm{b}}$ & $16.3 \pm 3.5^{\mathrm{c,d}}$ & $89.20 \pm 1.51^{\mathrm{b}, \mathrm{c}}$ & $63.3^{c}$ \\
\hline Cashew nut & $145.97 \pm 14.06^{\mathrm{a}}$ & $14.83 \pm 1.43^{\mathrm{a}}$ & $36.4 \pm 5.4^{b}$ & $87.66 \pm 1.74^{\mathrm{c}}$ & $90.3^{\mathrm{a}}$ \\
\hline
\end{tabular}

* Reference (casein with 7\% of lipids) and Control (casein with $15 \%$ of lipids). Values for a particular column followed by different letters differ significantly (p $<0.05)$. ( $\mathrm{n}=6$ rats, except for protein digestibility- $\mathrm{n}=4$ rats).

digestibility, and the baru almond to have the lowest (Table 4), and these values were close to those reported by Fernandes et al., 92\% for peanut and 79\% for baru almond [8]. According to the FAO [10], the true protein digestibility of cashew nut is $85 \%$, which was close to the value found in this study (Table 4). Therefore, nuts and peanut showed high values of protein digestibility (around 90\%), similar to that of fish protein, and the baru almond showed good protein digestibility (75\%), close to that of bean protein [20]. No published data were found regarding the protein digestibility of Brazil nut.

The protein quality of the edible seeds and nuts studied varied significantly, with PDCAAS values ranging from 57\% for baru almond to $90 \%$ for cashew nut (Table 4). Thus, the cashew nut has the best quality protein among these foods, mainly because of its essential amino acid profile (AAS $=103 \%$ ). The PDCAAS values for cashew nut and Brazil nut had not been reported before this study and represent the protein value of these foods for human nutrition, since the PDCAAS is the recommended method for estimating food protein quality for humans [16,20,23]. The PDCAAS value of the baru almond found in our study (57\%) was much lower than the reported value (73\%) [8]. This discrepancy in the quality of the protein of the baru almond is probably related to environmental variations that determine the high bio-diversity of native plants [4]. Therefore, it is important to consider the stratification of samples in nutritional investigations of native fruits [6]. In the other hand, the protein quality of peanut was similar to that reported in the literature (PDCAAS = $69 \%$ vs $70 \%$ ) [8].

The advantages and drawbacks of the intake of the edible seeds and nuts observed in this study, especially as protein sources for humans, are shown in Figure 1. On this basis, we recommend the inclusion of these seeds and nuts grown in Brazil in healthy diets, especially in 


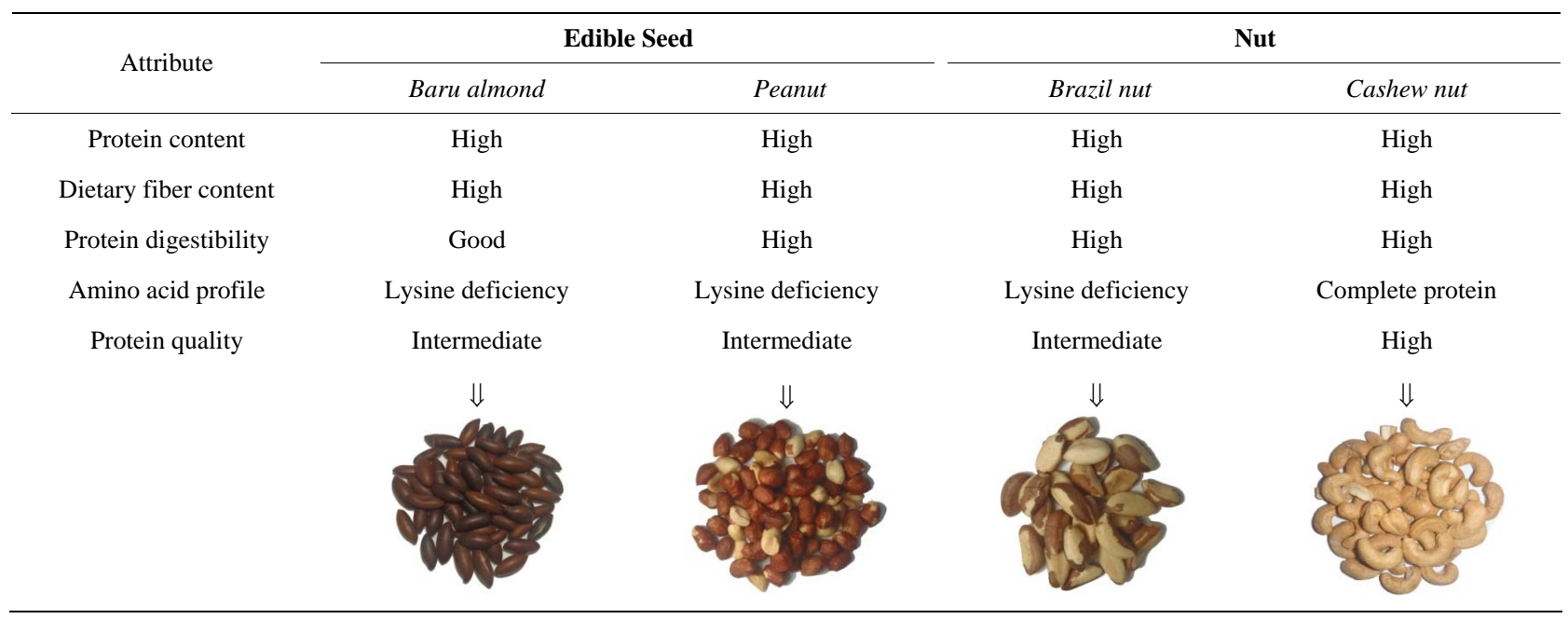

Figure 1. Schematic representation of the advantages and drawbacks of intake baru almond, peanut, Brazil nut and cashew nut, observed in this study.

vegetable-based diets, since a portion (20 g) of cashew nuts provides around $10 \%$ of the protein Dietary Reference Intake (DRI) for adults [24]. In addition, these foods contain a high density of other nutrients and bioactive compounds [5,7], and they can be used in different meals and dishes.

\section{Conclusion}

Edible seeds and nuts grown in Brazil provide a high density of energy and nutrients and good to high protein digestibility. Each of these foods contributes with a specific nutrient providing a health benefit: the baru almond is rich in dietary fiber; the peanut is a source of highly digestible protein; the Brazil nut provides the highest energy value and the cashew nut contains the best quality protein for humans. Therefore, we recommend making these edible seeds and nuts part of a healthy diet and as complementary sources of proteins in vegetable-based diets, especially the cashew nut.

\section{Acknowledgements}

This research was supported by Conselho Nacional de Desenvolvimento Científico e Tecnológico (CNPq, Brazil), Coordenação de Aperfeiçoamento de Pessoal de Nível Superior (CAPES, Brazil) and Fundação de Apoio à Pesquisa, Universidade Federal de Goiás (FUNAPE/ UFG, Brazil).

\section{REFERENCES}

[1] W. S. Judd, C. S. Campbell, E. A. Kellogg, P. F. Stevens and M. J. Donoghue, "Plant Systematics: A Phylogenetic Approach,” Sunderland, 2002.

[2] M. Venkatachalam and S. K. Sathe, "Chemical Com- position of Selected Edible Nut Seeds," Journal of Agricultural and Food Chemistry, Vol. 54, No. 13, 2006, pp. 4705-4714. doi:10.1021/jf0606959

[3] IBGE, "Produção da Extração Vegetal e da Sivicultura," Instituto Brasileiro de Geografia e Estatística, Rio de Janeiro, 2011.

[4] T. N. Soares, L. J. Chaves, M. P. C. Telles and J. A. F. Diniz-Filho, "Landscape Conservation Genetics of Dipteryx alata ("Baru” Tree: Fabaceae) from Cerrado Region of Central Brazil,” Genetica, Vol. 132, No. 1, 2008, pp. 9-19. doi:10.1007/s10709-007-9144-7

[5] J. B. Freitas and M. M. V. Naves, "Composição Química de Nozes e Sementes Comestíveis e sua Relação com a Nutrição e Saúde,” Revista de Nutrição, Vol. 23, No. 2, 2010, pp. 269-279. doi:10.1590/S1415-52732010000200010

[6] A. Toledo and B. Burlingame, "Biodiversity and Nutrition: A Common Path Toward Global Food Security and Sustainable Development," Journal of Food Composition and Analyses, Vol. 19, No. 6-7, 2006, pp. 477-483. doi:10.1016/j.jfca.2006.05.001

[7] J. Yang, "Brazil Nuts and Associated Health Benefits: A Review,” Food Science and Technology, Vol. 42, No. 10, 2009, pp. 1573-1580.

[8] D. C. Fernandes, J. B. Freitas, L. P. Czeder and M. M. V. Naves, "Nutritional Composition and Protein Value of the Baru (Dipteryx alata Vog.) Almond from the Brazilian Savanna," Journal of the Science of Food and Agriculture, Vol. 90, No. 10, 2010, pp. 1650-1655. doi:10.1002/jsfa.3997

[9] AOAC, “Official Methods of Analysis," Association of Official Analytical Chemists, Washington, 1990.

[10] FAO, "Amino-Acid Content of Foods and Biological Data on Proteins," Food and Agriculture Organization of the United Nations, Rome, 1970.

[11] E. G. Bligh and W. J. Dyer, "A Rapid Method of Total Lipid Extraction and Purification," Canadian Journal of Biochemistry and Physiology, Vol. 22, No. 8, 1959, pp. 


\section{1-917. doi:10.1139/059-099}

[12] L. Prosky, N. Asp, T. F. Schweizer, J. W. Devries and I. Furda, "Determination of Insoluble, Soluble, and Total Dietary Fiber in Foods and Food Products: Interlaboratory Study," Journal of the Association of Official Analytical Chemists, Vol. 71, No. 5, 1988, pp. 1017-1023.

[13] A. L. Merril and B. K. Watt, "Energy Value of Foods: Basis and Derivation," United States Department of Agriculture, Washington, 1973.

[14] S. Moore, D. H. Spackman and W. H. Stein, "Chromatography of Amino Acids on Sulfonated Polystyrene Resins,” Analytical Biochemistry, Vol. 30, No. 7, 1958, pp. 1185-1190.

[15] B. Lucas and A. Sotelo, "Effect of Different Alkalies, Temperatures and Hydrolysis Times on Tryptophan Determination of Pure Proteins and Foods," Analytical Biochemistry, Vol. 109, No. 1, 1980, pp. 192-197. doi:10.1016/0003-2697(80)90028-7

[16] WHO, Protein Quality Evaluation, "Protein and Amino Acid Requirements in Human Nutrition," World Health Organization, Geneva, 2007, pp. 93-102.

[17] NRC, "Guide for the Care and Use of Laboratory Animals,” National Academy Press, Washington, 1996.

[18] P. G. Reeves, F. N. Nielsen and G. C. Fahey, “AIN-93 Purified Diets for Laboratory Rodents: Final Report of the American Institute of Nutrition ad hoc Writing Com- mittee on the Reformulation of the AIN-76A Rodent Diet,” Journal of Nutrition, Vol. 123, No. 11, 1993, pp. 1939-1951.

[19] M. Muggia-Sullam, L. E. Matarese, L. L. Edwards and J. E. Fischer, "Efficacy of Two Elemental Diets: A Pair Feeding Study," Journal of Parenteral and Enteral Nutrition, Vol. 10, No. 1, 1986, pp. 45-48. doi:10.1177/014860718601000145

[20] FAO, "Protein Quality Evaluation,” Food and Agriculture Organization of the United Nations, Rome, 1991.

[21] M. Togashi and V. C. Sgarbieri, "Caracterização Química Parcial do Fruto do Baru (Dipteryx alata, Vog.),” Ciência e Tecnologia de Alimentos, Vol. 14, No. 1, 1994, pp. 8595.

[22] R. M. Moraes and E. Angelucci, “Chemical Composition and Amino Acid Contents of Brazilian Beans," Journal of Food Science, Vol. 36, No. 3, 1971, pp. 493-494. doi:10.1111/j.1365-2621.1971.tb06396.X

[23] G. Schaafsma, "The Protein Digestibility-Corrected Amino Acid Score,” Journal of Nutrition, Vol. 130, No. 7, 2000, pp. 1865-1867.

[24] Institute of Medicine, Food and Nutrition Board, "Dietary Reference Intakes for Energy, Carbohydrate, Fiber, Fat, Fatty Acids, Cholesterol, Protein, and Amino Acids," National Academy Press, Washington, 2005. 